\title{
Effect of Dosage of Alkaline Activator on the Properties of Alkali-Activated Slag Pastes
}

\author{
Zhenzhen Jiao $\mathbb{D}^{1,2,3}$ Ying Wang $\mathbb{D}^{1,2,3}$ Wenzhong Zheng $\mathbb{D}^{1,2,3}$ and Wenxuan Huang $\mathbb{D}^{1,2,3}$ \\ ${ }^{1}$ Key Lab of Structures Dynamic Behavior and Control of the Ministry of Education, Harbin Institute of Technology, \\ Harbin 150090, China \\ ${ }^{2}$ Key Lab of Smart Prevention and Mitigation of Civil Engineering Disasters of the \\ Ministry of Industry and Information Technology, Harbin Institute of Technology, Harbin 150090, China \\ ${ }^{3}$ School of Civil Engineering, Harbin Institute of Technology, Harbin 150090, China \\ Correspondence should be addressed to Wenzhong Zheng; zhengwenzhonghit@163.com
}

Received 30 August 2018; Revised 31 October 2018; Accepted 26 November 2018; Published 16 December 2018

Academic Editor: Francesco Ruffino

Copyright $(2018$ Zhenzhen Jiao et al. This is an open access article distributed under the Creative Commons Attribution License, which permits unrestricted use, distribution, and reproduction in any medium, provided the original work is properly cited.

This study focused on the engineering properties of alkali-activated slag (AAS) pastes prepared by mixing an activator consisting of sodium silicate and sodium hydroxide at room temperature. The water-to-slag ratio of AAS paste was kept constant at 0.35 by mass. AAS pastes were prepared using the activator with five different silicate moduli of $1,1.2,1.4,1.6$, and 1.8 and three different $\mathrm{Na}_{2} \mathrm{O}$ contents of $6 \%, 8 \%$, and $10 \%$. The results showed that both the silicate moduli and $\mathrm{Na}_{2} \mathrm{O}$ contents had significant effects on the engineering properties of AAS pastes. All the AAS pastes exhibited properties such as fast setting, good workability, and high early compressive strength. The final setting time varied from 9 to $36 \mathrm{~min}$, and the fluidity was in the range of $147-226 \mathrm{~mm}$. The $1 \mathrm{~d}$ compressive strength of all the AAS pastes, which could be easily achieved, had values above $55 \mathrm{MPa}$, whereas the highest strength obtained was $102 \mathrm{MPa}$ with the silicate modulus of 1 and $\mathrm{Na}_{2} \mathrm{O}$ content of $8 \%$ at room temperature. The drying shrinkage increased as the silicate modulus increased. Furthermore, the hydration products and microstructures of AAS pastes were explained according to the microanalysis methods.

\section{Introduction}

Due to the fast development of the construction industry all over the world, the demand for building materials has grown strong, especially in the developing countries. It is estimated that $85 \%$ of the total $\mathrm{CO}_{2}$ emissions originate from the cement industry [1]. Therefore, as the demand and subsequent production of cement increase, the $\mathrm{CO}_{2}$ emission increases, which can cause the greenhouse effect [2]. Blast furnace slag is an industrial by-product, produced during the process of making pig iron, and consists of calcium-rich and silicon-rich glass having latent hydraulic activity $[3,4]$. In addition, large amounts of slag are generated worldwide. For example, China produces a total of more than 2.4 million tonnes of slag annually, out of which, only a small portion (20-30\%) can be used efficiently, whereas a large portion $(70-80 \%)$ is deemed as the solid industrial waste [5]. Thus, in order to protect the environment and save resources, new environment friendly building materials must be explored. AAS was prepared by an alkaline activator and aluminosilicate materials. AAS cements are environment friendly cementitious materials, through which the industrial waste can be recycled in an effective way. In recent years, AAS cements have received significantly more attention as potential sustainable alternatives to Portland cement [6], which can convert industrial waste into green building materials.

Alkali-activated cementitious materials are greatly affected by the chemical composition of the alkaline activator [7-9]. In this regard, factors such as type and contents of the activator $[6,8,10-12]$, curing conditions [13-16], and mineral admixtures [17-19] in the alkali activation process were considered important. Živica [20] reported that AAS used by the $\mathrm{NaOH}$ solution, $\mathrm{Na}_{2} \mathrm{CO}_{3}$ solution, and water glass of three different types of activators showed an 
important acceleration for setting as compared to the ordinary Portland cement, and the setting time of slag activated by sodium silicate was the shortest. Jiao et al. [21] reported that the addition of $\mathrm{Na}_{2} \mathrm{CO}_{3}$ in the $\mathrm{NaOH}$ solution can prolong the setting time, increase the later compressive strength, and reduce the drying shrinkage of AAS paste compared with the alkaline activator of only $\mathrm{NaOH}$. Chang [22] studied the effects of concentrations of $\mathrm{SiO}_{2}$ and $\mathrm{Na}_{2} \mathrm{O}$ on the setting time and concluded that phosphoric acid can be used as an effective retarder. Wu et al. [23] reported that the activators with higher $\mathrm{pH}$ values can efficiently enhance the hydration process of AAS paste with more silicon and aluminum ions dissolving due to the weaker strengths of Si$\mathrm{O}$ and $\mathrm{Al}-\mathrm{O}$ bonds in the alkaline environment. Ravikumar and Neithalath [24] reported the effect of alkalinity of an alkali activator on the mechanical performance and $\mathrm{mi}$ crostructures of AAS materials. The results suggested that a higher alkalinity was helpful in improving the compressive strength, whereas the major hydration product was calcium silicate hydrate. Ahmari et al. [25] studied the development of compressive strength of alkali-activated binder based on copper mine tailings at $60-120^{\circ} \mathrm{C}$ of curing temperature. They showed that the strength first increased with the increase in initial temperature and then decreased when the temperature crossed a certain value. Lee and Lee [26] studied the reaction mechanism of a material produced by blending together sodium silicate and sodium hydroxide, which showed that a higher amount of slag resulted in a higher quantity of C-S-H gel and less aluminosilicate gel, which were produced as the hydration products. Many researchers [27-29] reported that the $\mathrm{Ca} / \mathrm{Si}$ ratio of calcium silicate hydrate in AAS was lower than that in ordinary Portland cement.

It is well known that AAS has excellent mechanical performance, good durability, and low porosity as compared to Portland cement. Gebregziabiher et al. [30] reported that the compressive strength of AAS with sodium silicate was 25 and $70 \mathrm{MPa}$ at 1 and 28 days, respectively, and that there was almost no increase thereafter until 56 days. Chi [31] showed that the resistance of AAS to sulfate attack was better than that of Portland cement, as shown by a lower weight loss and reduction in compressive strength of AAS concrete. Shi [32] found that the porosity of AAS was lower than that of the Portland cement, whereas the pore structure was also finer. However, there are also some disadvantages of rapid setting and high drying shrinkage of AAS pastes. Gu et al. [33] reported that the setting time of AAS was about $50 \mathrm{~min}$ at room temperature and tried to prolong the setting time by lowering the temperature. They also concluded that the drying shrinkage of AAS was 2-3 times that of the ordinary Portland cement.

Although many researchers focused on the properties of AAS, there is still a significant need for further investigations. The fast setting time and high early compressive strength of AAS were used for rapid repair construction and strengthening of concrete structures. The drying shrinkage is an important aspect for the durability of AAS pastes. In order to be better used for the construction, the more appropriate setting time, higher early compressive strength, and less drying shrinkage of AAS were needed to be studied. The composition of slag had a key influence on the properties and reaction mechanism of AAS [10]. The main alkaline activator was the mixture of sodium silicate and sodium hydroxide, which was controlled by the silicate modulus and $\mathrm{Na}_{2} \mathrm{O}$ content. Therefore, it is essential to investigate the effects of an optimum activator on the engineering properties of AAS pastes. The objective of this paper is to investigate the effects of silicate moduli and $\mathrm{Na}_{2} \mathrm{O}$ contents on fresh properties (setting time and fluidity) and hardened performance (compressive strength, drying shrinkage, and mass loss) of AAS pastes. The reaction mechanism of AAS was revealed using techniques of X-ray diffraction (XRD), Fourier transform infrared (FTIR) spectroscopy, scanning electron microscopy with energy dispersive X-ray spectroscopy (SEM/EDS), and mercury intrusion porosimetry (MIP).

\section{Materials and Methods}

2.1. Materials. Blast furnace slag was procured from the Tangshan steel plant, China, and its chemical composition is presented in Table 1. The specific surface area of slag was found to be $424 \mathrm{~m}^{2} / \mathrm{kg}$, whereas its specific gravity was determined to be 2.91 [21]. The specific surface area was tested by an electric Brinell permeability surface area analyzer (DBT-127; Wuxi Jianyi Instrument and Machinery Co. Ltd., China), according to the Chinese standard GB/T 80742008 [34]. The same sodium hydroxide was used in the previous study [21]. Sodium silicate solution consisting of $10.3 \% \mathrm{Na}_{2} \mathrm{O}, 32.1 \% \mathrm{SiO}_{2}$, and $57.6 \% \mathrm{H}_{2} \mathrm{O}$ was supplied by Julide Chemical Co. Ltd., Langfang, China. The alkaline activator of AAS pastes was prepared using sodium silicate and $\mathrm{NaOH}$ solutions.

2.2. Mixing Proportions. The AAS pastes were prepared from the slag in alkaline activators, whereas the mixing proportions are listed in Table 2. The water-to-slag ratio was kept constant at a value of 0.35 (by weight). To prepare AAS specimens, the activator was introduced into the slag powder in a bowl of cement paste mixer, in which the mixture was mixed at both low and high speeds for around $1.5 \mathrm{~min}$. There are five silicate moduli and three different $\mathrm{Na}_{2} \mathrm{O}$ contents for activators. The silicate moduli (Ms) consisted of 1, 1.2, 1.4, 1.6 , and 1.8 , whereas the $\mathrm{Na}_{2} \mathrm{O}$ contents were $6 \%, 8 \%$, and $10 \%$ (by weight of the slag). The codes "M1N6," "M1N8," and "M1N10" represented the silicate moduli of 1 and $\mathrm{Na}_{2} \mathrm{O}$ contents of $6 \%, 8 \%$, and $10 \%$, respectively, and so on.

2.3. Methods. The effects of silicate modulus and $\mathrm{Na}_{2} \mathrm{O}$ content on the setting times, fluidity, compressive strength, drying shrinkage, and microstructures of AAS pastes were investigated in this paper. The following methods have also been used by the previous study [21].

2.3.1. Test for the Setting Times. The setting times of alkaliactivated slag/fly ash were measured by Vicat in the previous 
TABle 1: Chemical composition of slag.

\begin{tabular}{lccccccccc}
\hline Oxide & $\mathrm{SiO}_{2}$ & $\mathrm{Al}_{2} \mathrm{O}_{3}$ & $\mathrm{CaO}$ & $\mathrm{Fe}_{2} \mathrm{O}_{3}$ & $\mathrm{~K}_{2} \mathrm{O}$ & $\mathrm{MgO}$ & $\mathrm{Na}_{2} \mathrm{O}$ & $\mathrm{SO}_{3}$ & $\mathrm{Others}$ \\
\hline Percentage (\%) & 32.83 & 17.19 & 36.69 & 0.38 & 0.37 & 8.20 & 0.65 & 1.94 & 1.75 \\
\hline
\end{tabular}

TABLE 2: The mixing proportions used for this study.

\begin{tabular}{lcccc}
\hline Code & Slag $(\mathrm{g})$ & Sodium silicate $(\mathrm{g})$ & $\mathrm{NaOH}(\mathrm{g})$ & $\mathrm{H}_{2} \mathrm{O}(\mathrm{g})$ \\
\hline M1N6 & 1000.0 & 181.2 & 53.2 & 233.7 \\
M1N8 & 1000.0 & 241.6 & 71.0 & 194.9 \\
M1N10 & 1000.0 & 301.9 & 88.7 & 156.1 \\
M1.2N6 & 1000.0 & 217.4 & 48.4 & 213.9 \\
M1.2N8 & 1000.0 & 289.9 & 64.5 & 168.5 \\
M1.2N10 & 1000.0 & 362.3 & 80.6 & 123.2 \\
M1.4N6 & 1000.0 & 253.6 & 43.5 & 194.1 \\
M1.4N8 & 1000.0 & 338.2 & 58.1 & 142.1 \\
M1.4N10 & 1000.0 & 422.7 & 72.6 & 90.2 \\
M1.6N6 & 1000.0 & 289.9 & 38.7 & 174.3 \\
M1.6N8 & 1000.0 & 386.5 & 51.6 & 115.8 \\
M1.6N10 & 1000.0 & 483.1 & 64.5 & 57.2 \\
M1.8N6 & 1000.0 & 326.1 & 33.9 & 154.5 \\
M1.8N8 & 1000.0 & 434.8 & 45.2 & 89.4 \\
M1.8N10 & 1000.0 & 543.5 & 56.5 & 24.2 \\
\hline
\end{tabular}

studies [22, 35-37]. The fresh pastes were immediately poured into a truncated cone mold $\left(h=40 \mathrm{~mm}, d_{\text {top }}=\right.$ $65 \mathrm{~mm}, d_{\text {bottom }}=70 \mathrm{~mm}$ ) to measure the setting time at room temperature. In accordance with the GB/T 1346-2011 standard [38], the setting times of AAS pastes were tested using a Vicat apparatus. The initial setting time was defined as the time between the initial contact of slag with the activating solution and that when the penetration value reached $25 \mathrm{~mm}$ (based upon the ASTM C191 standard). The final setting time corresponded to the point when the cyclic annular needle could not display a complete circular print on the AAS paste surface.

2.3.2. Fluidity Test. Based on the GB/T 8077-2012 standard [39], the fluidity of designed mixtures was measured using a truncated cone $\left(h=60 \mathrm{~mm}, d_{\text {top }}=36 \mathrm{~mm}, d_{\text {bottom }}=60 \mathrm{~mm}\right)$ at room temperature. Firstly, the fresh pastes were filled into a mold. After about $15 \mathrm{~s}$, the mold was lifted vertically. After another $30 \mathrm{~s}$, the diameters of the paste spread were measured along two perpendicular directions. The average diameter was interpreted as the fluidity of the pastes.

2.3.3. Compressive Strength Test. The paste samples were poured into prismatic molds of $40 \mathrm{~mm} \times 40 \mathrm{~mm} \times 160 \mathrm{~mm}$ dimensions, followed by shaking them manually. Afterwards, plastic foils were used to seal the surfaces of specimens to avoid any moisture losses. Then, the specimens were put in a standard room $\left(20 \pm 2^{\circ} \mathrm{C}\right.$ and $\left.\mathrm{RH}>95 \%\right)$ for 1 day. After demolding them, the specimens were kept in the standard room until tests for the age of strength were conducted. Compressive strength values were tested at 1,3 , 7,14 , and 28 days by means of a YAW-300 compressive strength analysis apparatus at a loading rate of $1.0 \mathrm{kN} / \mathrm{s}$. The mean values of six samples were interpreted as the compressive strength of AAS pastes for each age.

2.3.4. Drying Shrinkage and Mass Loss Tests. According to the Chinese standard JCT 603-2004 [40], the fresh pastes were poured into prismatic molds of $25 \mathrm{~mm} \times 25 \mathrm{~mm} \times$ $280 \mathrm{~mm}$ dimensions. The further procedure was the same as described in Section 2.3.3 until the demolding of specimens. The lengths of specimens were first determined, and then they were put in isothermal chambers $\left(20 \pm 2^{\circ} \mathrm{C}\right.$ and $\mathrm{RH}=50$ $\pm 5 \%)$. The drying shrinkage and mass of specimens were tested every day until 28 days. The drying shrinkages were monitored by using a comparator with a measuring accuracy of $0.001 \mathrm{~mm}$. Meanwhile, the mass values were measured by means of an electronic balance having an accuracy of $0.1 \mathrm{~g}$.

2.3.5. Microstructure Analytical Methods. After compressive strength tests at the corresponding curing time, the samples from the crushed prisms were kept in a mixture of alcohol and acetone $(1: 1 \mathrm{v} / \mathrm{v}$, respectively) for one week to stop the hydration process. Afterwards, the samples were taken out of the solution and dried in an oven at $60^{\circ} \mathrm{C}$ under vacuum. Some of the samples grounded into powder were passed through an $80 \mu \mathrm{m}$ sieve and, then, were used for XRD and FTIR spectroscopy analyses. Rest of the samples were used for SEM/EDS and MIP tests. In order to determine the hydration products and reaction mechanism of AAS pastes, the phase and characteristics of the bonds of raw material and products were determined using XRD (D8 ADVANCE manufactured by AXS, Germany) and FTIR spectroscopy (FTIR-650 spectrometer from China) analyses, respectively. The morphology and elemental analysis of the hydration products were determined using the SEM/EDS (ZEISS MERLIN Compact FE-SEM, Germany) technique. The pore structure of AAS was analyzed using MIP (AutoPore IV 9500, Micromeritics Instrument Ltd., USA).

\section{Results and Discussion}

3.1. Setting Times. Figure 1 shows the effects of silicate moduli and $\mathrm{Na}_{2} \mathrm{O}$ contents on the initial and final setting times of AAS pastes at room temperature. When the $\mathrm{Na}_{2} \mathrm{O}$ contents increased from $6 \%$ to $10 \%$, the initial and final setting times increased at the silicate modulus from 1.2 to 1.8 , respectively. However, the setting times decreased for the silicate modulus of 1 . Moreover, the optimum silicate modulus was 1.4 for longer setting times. For a higher $\mathrm{Na}_{2} \mathrm{O}$ content and silicate moduli in the alkaline activator, $\mathrm{Ca}$ from the decomposition of slag tends to form $\mathrm{Ca}(\mathrm{OH})_{2}$ rather than C-S-H due to the excess of $\mathrm{OH}^{-}$concentration in the earlier stage, resulting in the prolongation of time of $\mathrm{Ca}^{2+}$ precipitation $[6,41,42]$. The setting time of AAS pastes changed slightly, showing that all of the pastes can be used as 


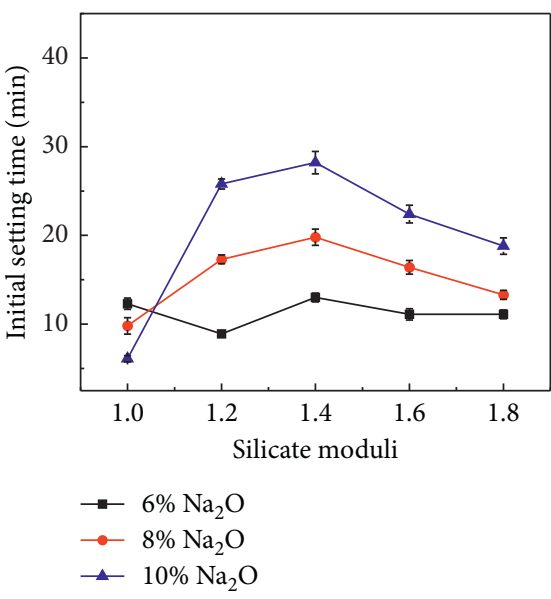

(a)

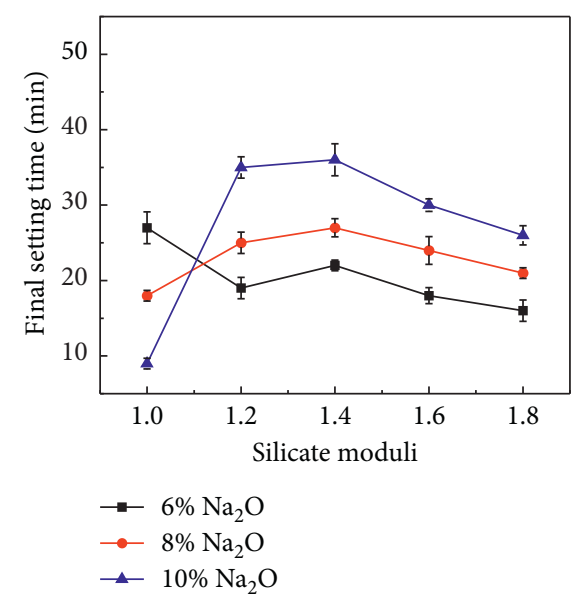

(b)

Figure 1: The setting times of AAS pastes: (a) initial setting time; (b) final setting time.

the building material of urgent construction or repair due to their fast setting property. These faster setting properties of AAS were ascribed to the rapid formation of initial C-S-H in the sodium silicate activator [10]. Another study [43] reported that the initial and final setting times of AAS were 76 and $106 \mathrm{~min}$, respectively, when the activator of water glass was used. In short, silicate moduli and $\mathrm{Na}_{2} \mathrm{O}$ contents of the alkaline activator have a combined effect on the setting properties of AAS pastes.

3.2. Fluidity. Based upon the silicate moduli and $\mathrm{Na}_{2} \mathrm{O}$ contents, the fluidity values of fresh pastes are shown in Figure 2. The fluidity of AAS pastes increased with the increase in silicate moduli, suggesting that increasing the silicate modulus can effectively improve the functioning of AAS pastes, which increased slightly once the silicate modulus went beyond the value of 1.4. The slag activated by $8 \% \mathrm{Na}_{2} \mathrm{O}$ presented higher fluidity than those activated by $6 \%$ and $10 \%$. The M1N10 specimen has no fluidity as a lot of reaction products are produced in a very short time, which is related to the shortest setting time of M1N10 (Figure 1). A previous research [44] has reported that the nature and concentration of the activator have vital effects on the rheological performance of AAS pastes. They proved that their rheology depends on both the silicate modulus and $\mathrm{Na}_{2} \mathrm{O}$ concentration for AAS pastes activated with water glass. Wang et al. [1] reported that the slump flow increased as the alkali agent increased from $4 \%$ to $8 \%$ in liquid-to-solid ratios of $0.35,0.40$, and 0.45 in the alkali-activated ladle furnace slag geopolymer. These results were mainly attributed to the stickiness of alkali metal silicate solution.

3.3. Compressive Strength. The effects of silicate moduli and $\mathrm{Na}_{2} \mathrm{O}$ contents on the compressive strength of AAS pastes within the studied periods are presented in Figure 3. For the $\mathrm{Na}_{2} \mathrm{O}$ content of $8 \%$, highest compressive strength was observed, whereas beyond this content of $\mathrm{Na}_{2} \mathrm{O}$ (e.g., $10 \%$ ), the strength decreased. Some previous studies $[45,46]$ have

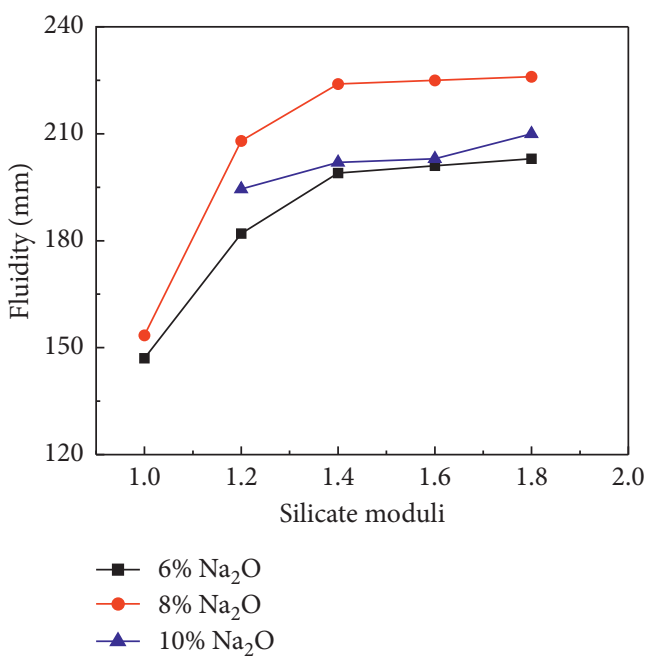

Figure 2: The effects of the silicate moduli and $\mathrm{Na}_{2} \mathrm{O}$ contents on the fluidity of AAS pastes.

shown that the excess content of $\mathrm{Na}_{2} \mathrm{O}$ in the alkali activator is used for charge balancing the $\mathrm{Al}^{3+}$ in the process of polymerization reaction. On the contrary, when the $\mathrm{Na}_{2} \mathrm{O}$ contents were $6 \%$ and $8 \%$, the specimens with the silicate moduli of 1.4 and 1.6 exhibited relatively good compressive strengths at the early and later stages of the process. Moreover, all the specimens showed higher early strengths (more than $55 \mathrm{MPa}$ after $1 \mathrm{~d}$ ), whereas the highest 1-day compressive strength obtained was $102 \mathrm{MPa}$ at room temperature. The compressive strength values after 1 day lied within the range of $55 \%-91 \%$, which were close to those obtained after 28 days. This indicated that the sodium silicate solution-activated slag pastes can enhance the early compressive strength development. The high early compressive strength can be suitable for emergency construction and repair works. Aydin and Baradan [10] showed that the C-S$\mathrm{H}$ gel was rapidly formed for improving the early strength. Puertas and Torres-Carrasco [47] concluded that the gel 


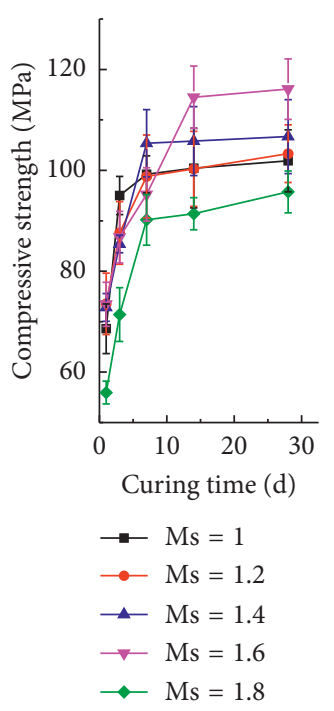

(a)

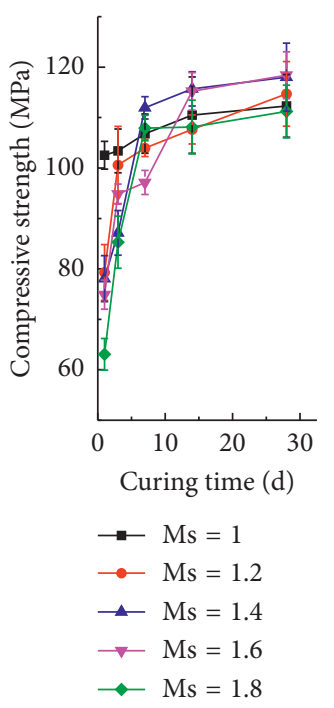

(b)

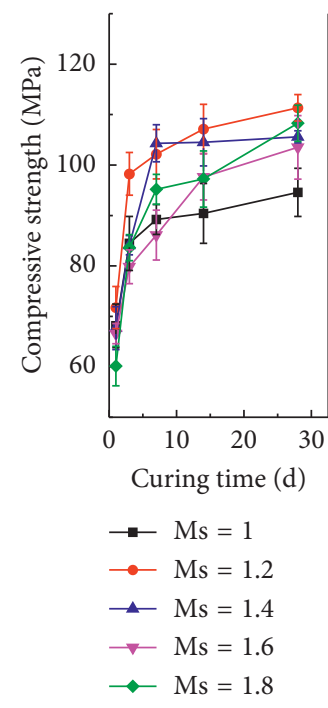

(c)

Figure 3: The effects of silicate moduli and $\mathrm{Na}_{2} \mathrm{O}$ contents on compressive strength of AAS pastes. (a) $6 \% \mathrm{Na}_{2} \mathrm{O}$. (b) $8 \% \mathrm{Na}_{2} \mathrm{O}$. (c) $10 \%$ $\mathrm{Na}_{2} \mathrm{O}$.

formed by the activation of sodium silicate had a more condensed structure during the early stages.

3.4. Drying Shrinkage. The effects of silicate moduli and $\mathrm{Na}_{2} \mathrm{O}$ contents on the drying shrinkage before 28 days are shown in Figure 4. As can be observed from Figure 4, the drying shrinkage of AAS pastes increased as the silicate modulus increased. The drying shrinkage values of specimens with $\mathrm{Ms}=1.2,1.4,1.6$, and 1.8 were $1.12,1.43,1.59$, and 2.01 times that of specimens with $\mathrm{Ms}=1$ with $8 \% \mathrm{Na}_{2} \mathrm{O}$ content after 28 days, respectively. In addition, when the silicate modulus was 1 and 1.2, the drying shrinkage increased as the $\mathrm{Na}_{2} \mathrm{O}$ contents increased from $6 \%$ to $8 \%$, after which the value decreased for $10 \% \mathrm{Na}_{2} \mathrm{O}$ content. However, the drying shrinkage increased with the increase in $\mathrm{Na}_{2} \mathrm{O}$ content for the silicate moduli of 1.4 and 1.8. A previous study [1] has shown that the drying shrinkage increased with the increase in alkali agent from $4 \%$ to $8 \%$ at the liquid-toslag ratios of $0.35,0.40$, and 0.45 . In addition, Komnitsas et al. [45] reported that the excess $\mathrm{KOH}$ did not react with the raw material. Neto et al. [48] concluded that the higher content of sodium silicate resulted in a higher drying shrinkage of AAS pastes. Based upon these results, it can be concluded that the silicate moduli played a more important role in the drying shrinkage of AAS pastes than the $\mathrm{Na}_{2} \mathrm{O}$ contents.

3.5. Mass Loss. Figure 5 shows the mass loss (expressed as the mass percent of the total specimen) of AAS pastes for different $\mathrm{Na}_{2} \mathrm{O}$ contents $(6 \%, 8 \%$, and $10 \%)$ and silicate moduli ( $\mathrm{Ms}=1,1.2,1.4,1.6$, and 1.8) during the drying shrinkage testing within 28 days. Regardless of the $\mathrm{Na}_{2} \mathrm{O}$ content of the specimens, the mass loss increased as the silicate modulus increased. In addition, the mass loss decreased with the increase in the content of $\mathrm{Na}_{2} \mathrm{O}$. A previous study [13] has shown that the water loss decreased as the content of $\mathrm{Na}_{2} \mathrm{O}$ increased from $4 \%$ to $6 \%$ in AAS cement. This may indicate that more free water existed in specimens having a lower content of $\mathrm{Na}_{2} \mathrm{O}$ and higher silicate modulus. However, Lee et al. [49] have reported contrary results and concluded that the higher dosage of sodium silicate resulted in the loss of less evaporable water, as more water took part in the polymerization reaction. According to a previous study [50], there was a strong relationship between the drying shrinkage and mass loss for Portland cement. However, for AAS pastes, the relationship was not clear, although the drying shrinkage and mass loss of AAS pastes followed the same trend due to the effect of silicate moduli, whereas the mass loss was found not to be directly related to the drying shrinkage due to the effect of $\mathrm{Na}_{2} \mathrm{O}$ content.

3.6. XRD Analysis. Figure 6 shows the XRD diffractograms of AAS pastes for various $\mathrm{Na}_{2} \mathrm{O}$ contents and silicate moduli at an early age. All the hydration products of the specimens showed some weak peaks, which can be identified as omphacite $\left((\mathrm{NaCa})(\mathrm{AlMg}) \mathrm{SiO}_{6}\right)$, larnite $\left(\mathrm{Ca}_{2} \mathrm{SiO}_{4}\right)$, poorly crystalline $\mathrm{C}-\mathrm{S}-\mathrm{H}$, and calcite $\left(\mathrm{CaCO}_{3}\right)$. In addition, calcium aluminum silicate $\left(\mathrm{Ca}_{2} \mathrm{Al}_{2} \mathrm{SiO}_{7}\right)$ was only found in the M1N10 specimen, whereas the peaks of C-S-H and calcite overlapped with each other. There was almost no significant difference between the crystal phases of the hydration products in the specimens for different contents of $\mathrm{Na}_{2} \mathrm{O}$ or silicate moduli. These results were in accordance with those obtained in a previous study [51], in which the researchers also concluded that there were no obvious peaks, indicating that significant quantities of crystalline hydration products were not formed at room temperature. However, Rashad et al. [52] concluded that the intensity of amorphous hump increased as the $\mathrm{Na}_{2} \mathrm{O}$ content increased from $3.5 \%$ to $6.5 \%$, which resulted in a higher compressive strength. 


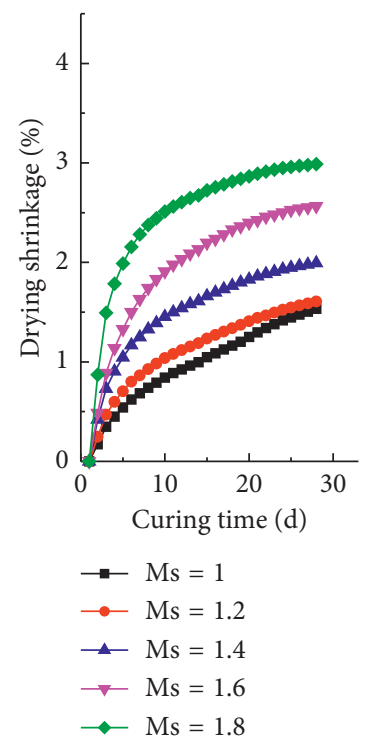

(a)

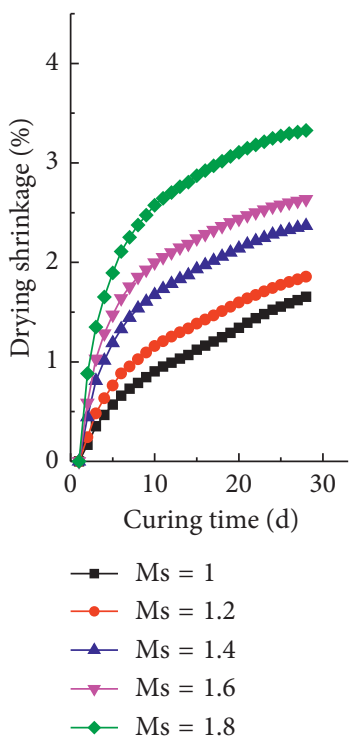

(b)

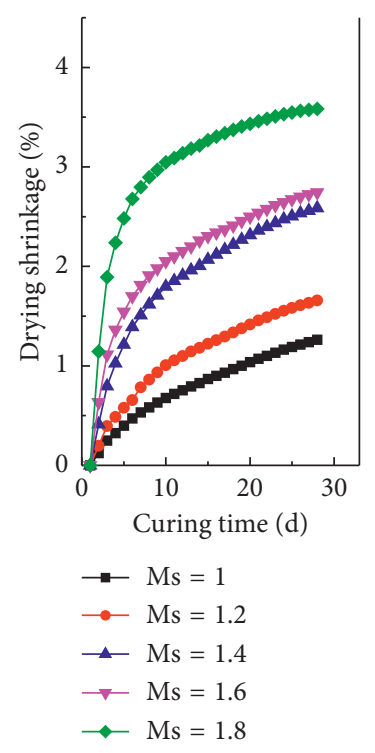

(c)

Figure 4: The effects of the silicate moduli and $\mathrm{Na}_{2} \mathrm{O}$ contents on drying shrinkage of AAS pastes. (a) $6 \% \mathrm{Na}_{2} \mathrm{O}$. (b) $8 \% \mathrm{Na}_{2} \mathrm{O}$. (c) $10 \% \mathrm{Na}_{2} \mathrm{O}$.

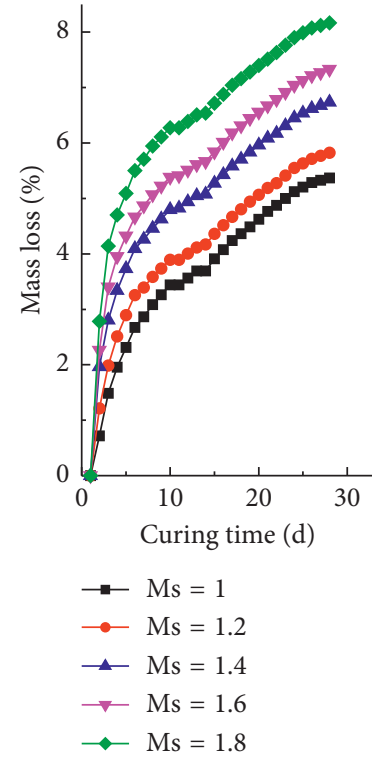

(a)

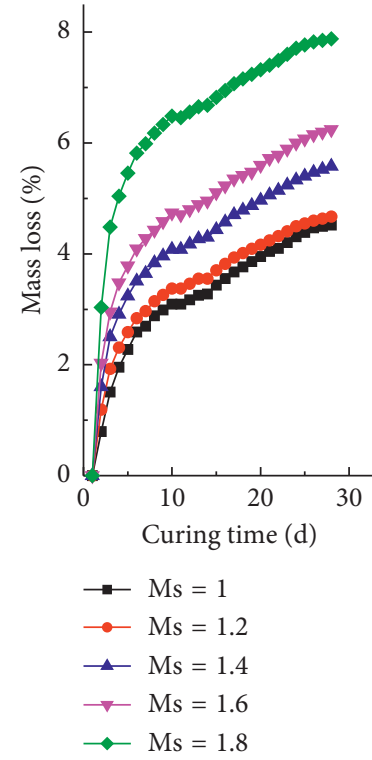

(b)

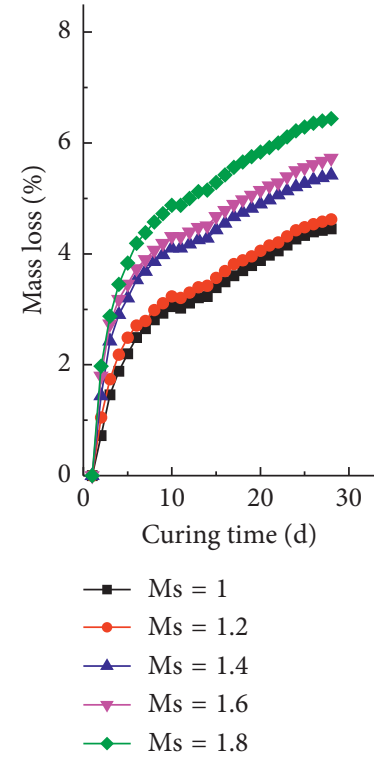

(c)

Figure 5: The effects of the silicate moduli and $\mathrm{Na}_{2} \mathrm{O}$ contents on the mass loss of AAS pastes. (a) $6 \% \mathrm{Na}_{2} \mathrm{O}$. (b) $8 \% \mathrm{Na}_{2} \mathrm{O}$. (c) $10 \% \mathrm{Na}_{2} \mathrm{O}$.

Additionally, there was no indication to prove the existence of $\mathrm{Ca}(\mathrm{OH})_{2}$ compared to the ordinary Portland cement paste [33].

3.7. FTIR Spectroscopy Analysis. The FTIR spectra of AAS pastes are shown in Figure 7. In pastes, the reaction products had the stretching and bending vibrations of $\mathrm{H}-\mathrm{O}-\mathrm{H}$ groups at $3458 \mathrm{~cm}^{-1}$ and $1651 \mathrm{~cm}^{-1}$, respectively. Both the wave numbers shifted towards the larger wavelength as compared to the raw slag (at $3435 \mathrm{~cm}^{-1}$ ), indicating that more hydration products were formed with the progress of the polymerization process after one day. The band located at $1454 \mathrm{~cm}^{-1}$ was related to the existence of $\mathrm{CO}_{3}{ }^{2-}$ and corresponded to the production of calcite [53], which was in agreement with the XRD results discussed in Section 3.6. The asymmetric stretching vibration of $\mathrm{Si}-\mathrm{O}$ bonds was located at $964 \mathrm{~cm}^{-1}$, which represented C-S-H in the hydration product. The bands at $675 \mathrm{~cm}^{-1}$ were assigned to Al-O bonds, which implied that $\mathrm{Al}$ replaced $\mathrm{Si}$ in the siliconoxygen tetrahedron [54]. The wavenumber of the Al-O bond was lower after the activation than that of the unreacted slag (at $694 \mathrm{~cm}^{-1}$ ), which indicated that the reaction of AAS included the dissolution of $\mathrm{Al}^{3+}$ from the slag and the 


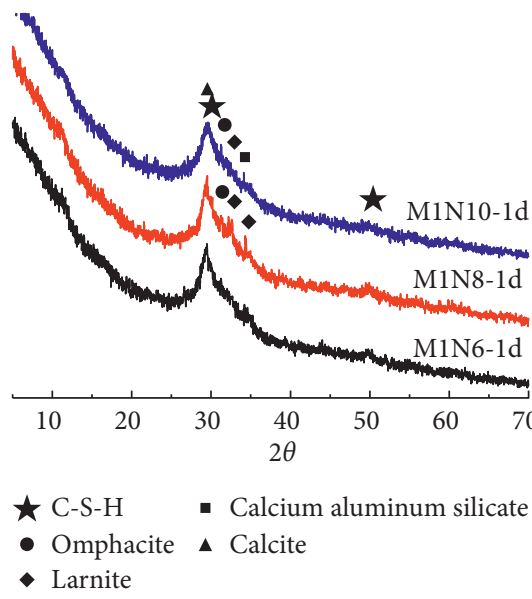

(a)

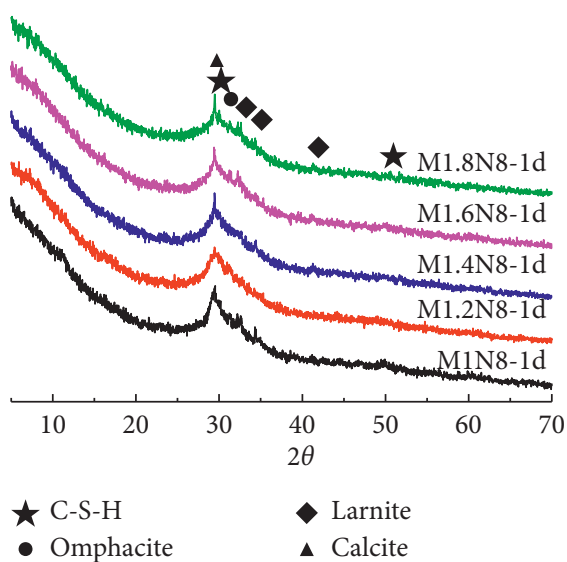

(b)

Figure 6: The XRD diffractograms of AAS pastes at different $\mathrm{Na}_{2} \mathrm{O}$ contents (a) and silicate moduli (b).

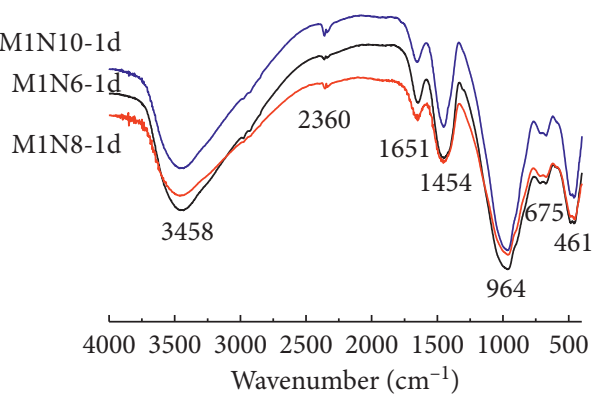

(a)

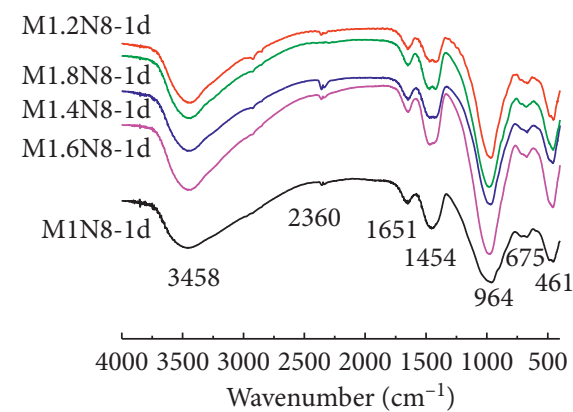

(b)

FIgURE 7: FTIR spectra of AAS pastes: (a) $\mathrm{Na}_{2} \mathrm{O}$ contents; (b) silicate moduli.

recombination of $\mathrm{Al}^{3+}$ with silicate anions [33]. The bands at $461 \mathrm{~cm}^{-1}$ were attributed to Si-O bending. The results were in accordance with the information of $\mathrm{C}-(\mathrm{A})-\mathrm{S}-\mathrm{H}$, which was identified using the XRD analysis. It can be concluded that the sodium silicate activator had a significant effect on the degree of polymerization of AAS pastes at an early age.

3.8. SEM/EDS Analysis. The microstructures of AAS pastes synthesized using different contents of $\mathrm{Na}_{2} \mathrm{O}$ and silicate moduli are shown in Figures 8 and 9. As can be observed from Figures 8(a) and 8(c), the hardened AAS pastes with $6 \%$ and $8 \% \mathrm{Na}_{2} \mathrm{O}$ consisted of rod-like particles on the surface of the gel, which were the main reaction products (such as C-(A)-S-H and N-A-S-H) [28, 55]. Moreover, the AAS paste of M1.2N8 was denser than that of M1.2N6, which was in accordance with the result obtained regarding the development of compressive strength and discussed in Section 3.3. This was due to that the strength of M1.2N8 was higher than that of M1.2N6 after 28 days. The products of AAS pastes mainly consisted of $\mathrm{Si}, \mathrm{Ca}, \mathrm{Na}$, and $\mathrm{Al}$, while the amount of $\mathrm{Mg}$ produced was relatively low. The chemical elements of hydration products were tested using energy dispersive X-ray spectroscopy (EDS), and the results of $\mathrm{Ca} / \mathrm{Si}$ were found to be 0.961 and 1.171 for M1.2N6 and M1.2N8 specimens, respectively. It may be concluded that the activator has higher $\mathrm{pH}$ for larger $\mathrm{Na}_{2} \mathrm{O}$ contents, and vice versa. The increase in $\mathrm{pH}$ can accelerate the solubility of $\mathrm{Ca}$ in the dissolved slag. The silicate modulus has a more pronounced effect on the degree of polymerization of AAS. In addition, silicate modulus also determined the structure and morphology of reaction products [56]. SEM images of AAS pastes with different silicate moduli $(\mathrm{Ms}=1,1.2,1.4,1.6$, and 1.8 ) and $\mathrm{Na}_{2} \mathrm{O}$ content of $8 \%$ are shown in Figures $8(\mathrm{~b})-8(\mathrm{f})$, respectively. The network of fine particles and layered silicate minerals were noticeably observed for the M1N8 specimen. The M1.2N8 sample showed rod-like morphology of the reaction products, and the matrices looked rather dense. The alkali-activated products presented a homogeneous and close-grained structure (calcium silicate hydrate gel), whereas the $\mathrm{Ca} / \mathrm{Si}$ ratio of the gel was found to be 1.4 for the M1.4N8 specimen. In addition, a network of fine particles was also observed in the M1.6N8 specimen. Meanwhile, the paste was close-grained hydration products and made the structure more compact compared with the M1N8 specimen. The surface of the M1.8N8 specimen was covered with a significant number of rod-like particles and porous structure, resulting in weak bonding strength. These results were in agreement with the development of mechanical properties, as the compressive strength of the M1.8N8 

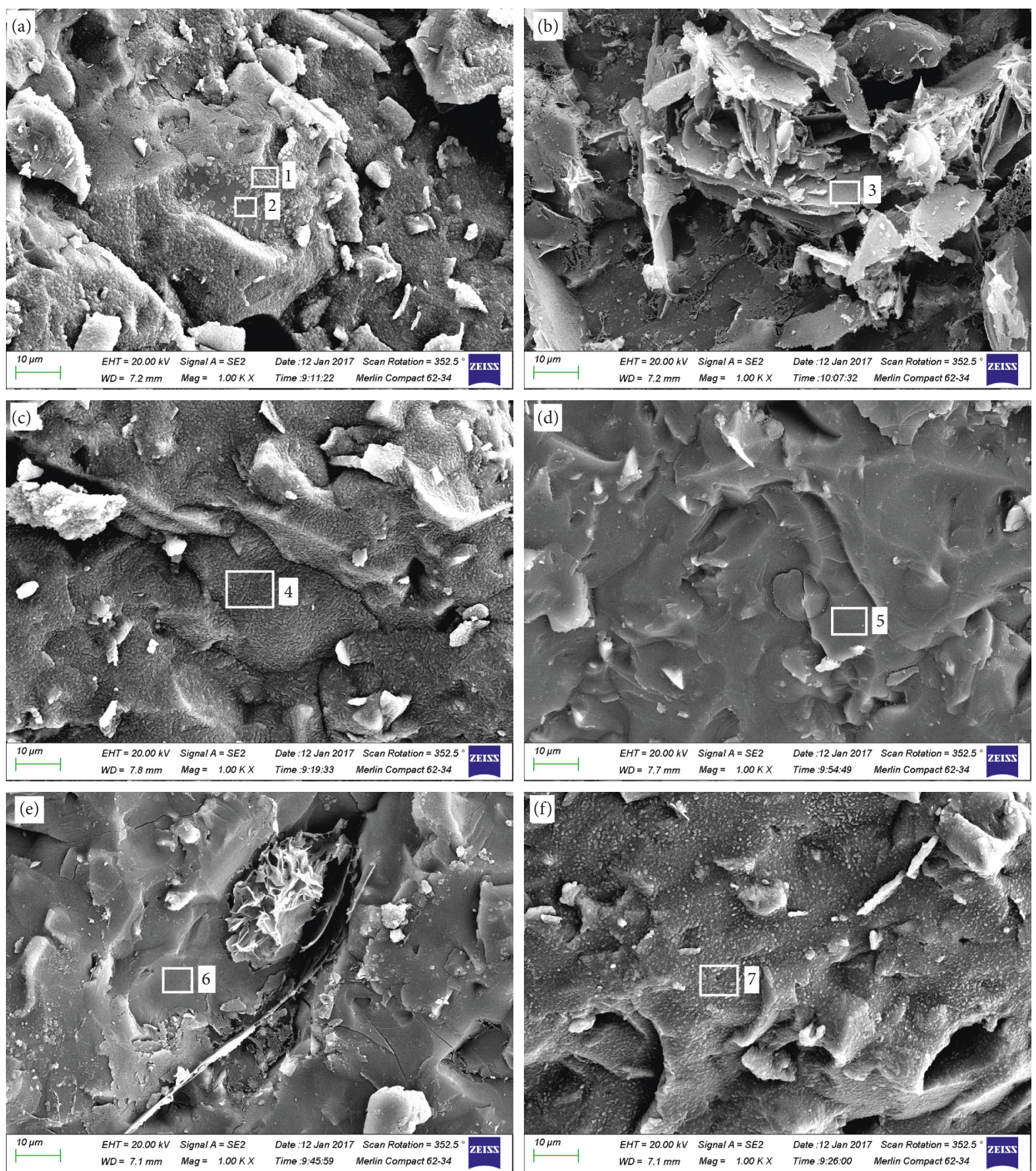

FIGURE 8: SEM images of AAS pastes for 28 days: (a) M1.2N6.

(b) M1N8. (c) M1.2N8. (d) M1.4N8. (e) M1.6N8. (f) M1.8N8.

specimen was lower than those of M1.4N8 and M1.6N8 specimens. Rattanasak et al. [57] reported that the difference in gel formation affected the binding capacity and strength of geopolymer binder. Moreover, there were little crystalline products in all the samples.

The EDS analysis revealed that the hydration products have lots of $\mathrm{O}, \mathrm{Na}, \mathrm{Al}, \mathrm{Si}$, and $\mathrm{Ca}$ elements, whereas the $\mathrm{Ca} / \mathrm{Si}$ ratio was in the range of $0.8-1.4$. The main product of AAS pastes was C-S-H (or N-A-S-H) gel, which was amorphous at room temperature. In addition, $\mathrm{Na}$ and $\mathrm{Al}$ elements were found to be present in the structure of calcium silicate hydrate gel, as observed by the EDS. Meanwhile, the atomic percentages of $\mathrm{Na}$ and $\mathrm{Al}$ were found to be $1.45-27.77 \%$ and $2.99-11.06 \%$, respectively. A previous study [58] concluded that a higher silicate modulus of the activator can accelerate the rate of polymerization and form lower crystalline products.

3.9. MIP Analysis. Table 3 presents the pore sizes of AAS pastes. The pore size was tested between 5 and $360000 \mathrm{~nm}$ 

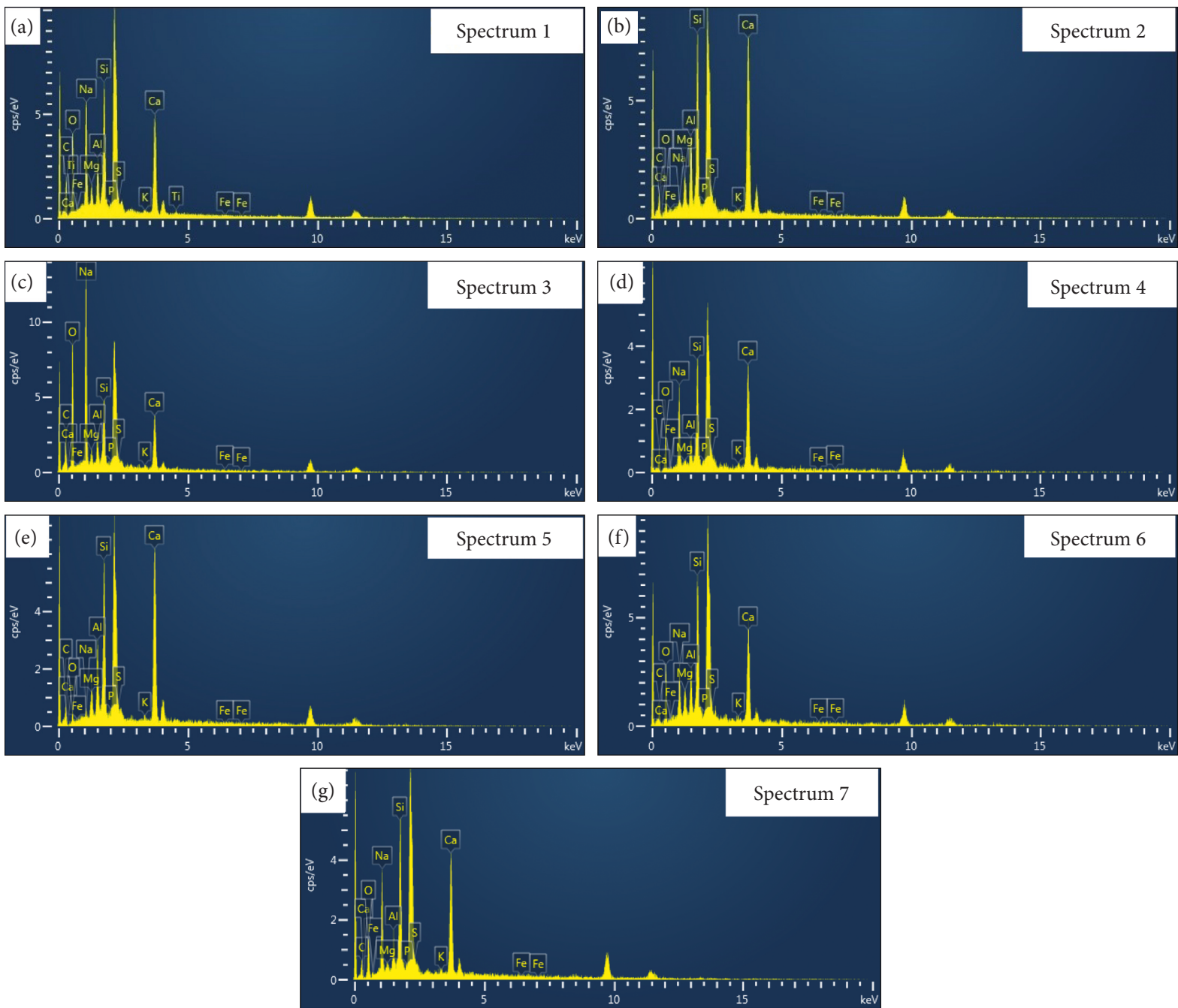

Figure 9: EDS images of AAS pastes corresponding to Figure 8: (a, b) M1.2N6. (c) M1N8. (d) M1.2N8. (e) M1.4N8. (f) M1.6N8. (g) M1.8N8.

TABLE 3: The classifications of pores in the AAS pastes (according to the International Union of Pure and Applied Chemistry system).

\begin{tabular}{lcccc}
\hline & Micropores & Mesopores & Macropores & Voids and microcracks \\
\hline Pore size $(\mathrm{mm})$ & $<2.5$ & $2.5-50$ & $50-10000$ & $>10000$ \\
\hline
\end{tabular}

using AutoPore IV 9500. Therefore, there were three types of pore sizes in the AAS pastes, namely, the mesopores, macropores, and voids and microcracks. The effect of silicate modulus on the pore size distribution of AAS pastes is shown in Figure 10. Figure 10(a) shows that the pore volume decreased with the increase in silicate modulus, except for the M1.8N8 specimen, indicating that a lower silicate modulus resulted in a larger pore volume. Figure 10(b) indicated that the volume of mesopores increased, whereas the volume of macropores decreased with the increase in silicate modulus. The larger volume of mesopores resulted in higher drying shrinkage values [33], which was consistent with the development of drying shrinkage, as discussed in Section 3.4. It can also be seen that the increase in silicate modulus led to a lower volume of macropores along with smaller voids and microcracks (M1.8N8 specimen had the largest voids and microcracks), which revealed that more hydration products had filled the larger pores, thus making it denser with the increase in silicate modulus at the same curing ages [59]. The porosities and pore size distribution of M1.6N8 and M1.4N8 were almost the same, which could explain the fact that both of them had relatively higher compressive strengths as mentioned above in Section 3.3.

\section{Conclusions}

Based on the experimental results, the following main conclusions can be drawn from the study:

(1) The initial and final setting times were in the range of 6.1-28.2 min and 9-36 min, respectively. The fluidity of AAS pastes was between 147 and $226 \mathrm{~mm}$. 


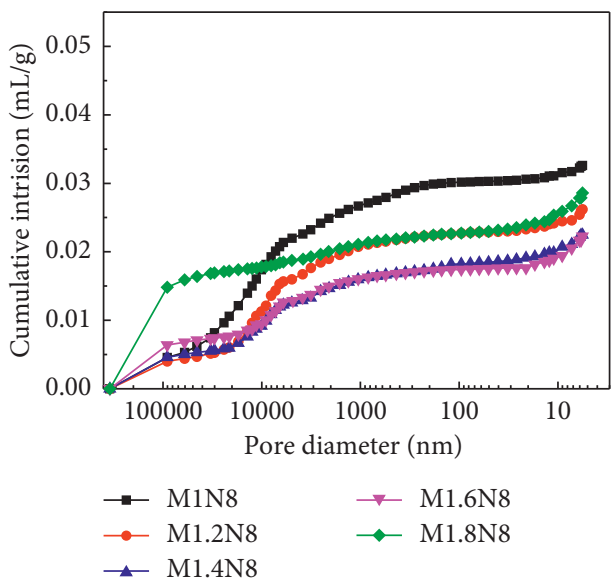

(a)

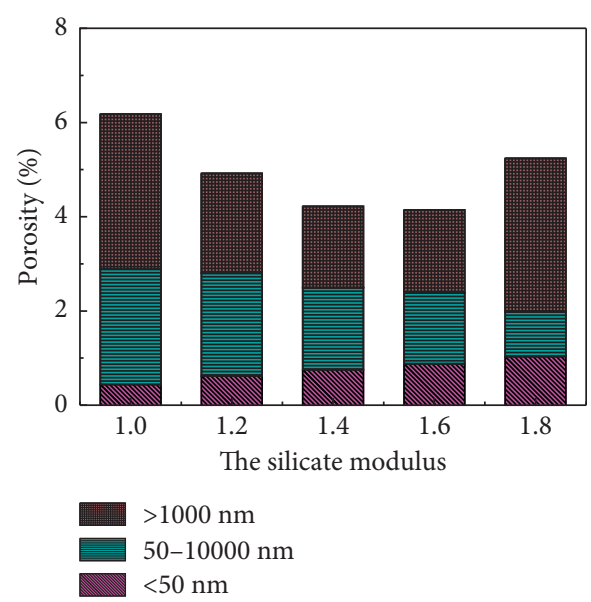

(b)

FIGURE 10: Pore size distribution of AAS pastes with different silicate moduli: (a) cumulative intrusion; (b) porosity.

(2) AAS pastes also exhibited higher early compressive strengths, whereas the highest 1-day compressive strength was found to be $102 \mathrm{MPa}$ at room temperature.

(3) Both the drying shrinkage and mass loss increased as the silicate modulus increased during the curing process. However, with the increase of $\mathrm{Na}_{2} \mathrm{O}$ content, the drying shrinkage increased, while the mass loss decreased when the silicate modulus went beyond the value of 1.2. The mechanism of drying shrinkage was not entirely due to the mass loss and had a strong relationship between the volume of micropores and hydration products.

(4) The dominant reaction products of AAS pastes were amorphous $\mathrm{C}-\mathrm{S}-\mathrm{H}$ and omphacite. The hydration products have high amounts of $\mathrm{O}, \mathrm{Na}, \mathrm{Al}, \mathrm{Si}$, and $\mathrm{Ca}$ elements, whereas the products of the M1.4N8 specimen exhibited a homogeneous and closegrained microstructure. Furthermore, the $\mathrm{Ca} / \mathrm{Si}$ ratio was found to be ca. 1.4.

(5) Lower values of porosity and volume of voids and microcracks were observed for the specimen with silicate moduli of 1.4 and 1.6 having $8 \% \mathrm{Na}_{2} \mathrm{O}$, which explained the excellent mechanical performance of the specimen.

\section{Data Availability}

All the data in this paper were obtained by performing the experiment. All the experiments were according to the corresponding test procedures. Data sharing is not applicable to this article as no datasets were generated or analyzed during the current study.

\section{Conflicts of Interest}

The authors declare that there are no conflicts of interest regarding the publication of this paper.

\section{Acknowledgments}

This study was supported by the National Natural Science Foundation of China (51478142).

\section{References}

[1] W. C. Wang, H. Y. Wang, and H. C. Tsai, "Study on engineering properties of alkali-activated ladle furnace slag geopolymer," Construction and Building Materials, vol. 123, pp. 800-805, 2016.

[2] A. M. Rashad, "A comprehensive overview about the influence of different additives on the properties of alkali-activated slag-a guide for civil engineer," Construction and Building Materials, vol. 47, pp. 29-55, 2013.

[3] Y. J. Zhang, L. C. Liu, L. L. Ni, and B. L. Wang, "A facile and low-cost synthesis of granulated blast furnace slag-based cementitious material coupled with $\mathrm{Fe}_{2} \mathrm{O}_{3}$ catalyst for treatment of dye wastewater," Applied Catalysis B: Environmental, vol. 138-139, pp. 9-16, 2013.

[4] N. Mobasher, S. A. Bernal, and J. L. Provis, "Structural evolution of an alkali sulfate activated slag cement," Journal of Nuclear Materials, vol. 468, pp. 97-104, 2016.

[5] F. Puertas, S. Martínez-Ramírez, S. Alonso, and T. Vázquez, "Alkali-activated fly ash/slag cements," Cement and Concrete Research, vol. 30, no. 10, pp. 1625-1632, 2000.

[6] S. A. Bernal, "Effect of the activator dose on the compressive strength and accelerated carbonation resistance of alkali silicate-activated slag/metakaolin blended materials," Construction and Building Materials, vol. 98, pp. 217-226, 2015.

[7] Y. F. Gong, Y. H. Fang, Y. R. Yan, and L. Q. Chen, "Investigation on alkali activated recycled cement mortar powder cementitious material," Materials Research Innovations, vol. 18, no. 2, pp. 784-787, 2014.

[8] L. Xin, X. Jin-yu, L. Weimin, and B. Erlei, "Effect of alkaliactivator types on the dynamic compressive deformation behavior of geopolymer concrete," Materials Letters, vol. 124, pp. 310-312, 2014.

[9] T. Phoo-ngernkham, A. Maegawa, N. Mishima, S. Hatanaka, and P. Chindaprasirt, "Effects of sodium hydroxide and sodium silicate solutions on compressive and shear bond strengths of FA-GBFS geopolymer," Construction and Building Materials, vol. 91, pp. 1-8, 2015. 
[10] S. Aydin and B. Baradan, "Effect of activator type and content on properties of alkali-activated slag mortars," Composites Part B: Engineering, vol. 57, pp. 166-172, 2014.

[11] C. Elibol and O. Sengul, "Effects of activator properties and ferrochrome slag aggregates on the properties of alkaliactivated blast furnace slag mortars," Arabian Journal for Science and Engineering, vol. 41, no. 4, pp. 1561-1571, 2015.

[12] M. Ben Haha, G. Le Saout, F. Winnefeld, and B. Lothenbach, "Influence of activator type on hydration kinetics, hydrate assemblage and microstructural development of alkali activated blast-furnace slags," Cement and Concrete Research, vol. 41, no. 3, pp. 301-310, 2011.

[13] R. J. Thomas, D. Lezama, and S. Peethamparan, "On drying shrinkage in alkali-activated concrete: improving dimensional stability by aging or heat-curing," Cement and Concrete Research, vol. 91, pp. 13-23, 2017.

[14] C. Song, Y. C. Choi, and S. Choi, "Effect of internal curing by superabsorbent polymers-internal relative humidity and autogenous shrinkage of alkali-activated slag mortars," Construction and Building Materials, vol. 123, pp. 198-206, 2016.

[15] A. M. Rashad, D. M. Sadek, and H. A. Hassan, "An investigation on blast-furnace stag as fine aggregate in alkaliactivated slag mortars subjected to elevated temperatures," Journal of Cleaner Production, vol. 112, pp. 1086-1096, 2016.

[16] C. Bilim, O. Karahan, C. D. Atiş, and S. İlkentapar, "Influence of admixtures on the properties of alkali-activated slag mortars subjected to different curing conditions," Materials and Design, vol. 44, pp. 540-547, 2013.

[17] F. Messina, C. Ferone, F. Colangelo, and R. Cioffi, "Low temperature alkaline activation of weathered fly ash: influence of mineral admixtures on early age performance," Construction and Building Materials, vol. 86, pp. 169-177, 2015.

[18] M. Murmu and S. P. Singh, "Influence of mineral admixtures on strength and hydration products of lime-activated slag cement," Advances in Cement Research, vol. 26, no. 6, pp. 334-343, 2014.

[19] Z. Li, Z. Pan, Y. Liu et al., "Effects of mineral admixtures and lime on disintegration of alkali-activated slag exposed to $50^{\circ} \mathrm{C}$," Construction and Building Materials, vol. 70, pp. 254-261, 2014.

[20] V. Živica, "Effects of type and dosage of alkaline activator and temperature on the properties of alkali-activated slag mixtures," Construction and Building Materials, vol. 21, no. 7, pp. 1463-1469, 2007.

[21] Z. Jiao, Y. Wang, W. Zheng, and W. Huang, "Effect of dosage of sodium carbonate on the strength and drying shrinkage of sodium hydroxide based alkali-activated slag paste," Construction and Building Materials, vol. 179, pp. 11-24, 2018.

[22] J. J. Chang, "A study on the setting characteristics of sodium silicate-activated slag pastes," Cement and Concrete Research, vol. 33, no. 7, pp. 1005-1011, 2003.

[23] X. Wu, W. Jiang, and D. M. Roy, "Early activation and properties of slag cement," Cement and Concrete Research, vol. 20, no. 6, pp. 961-974, 1990.

[24] D. Ravikumar and N. Neithalath, "Effects of activator characteristics on the reaction product formation in slag binders activated using alkali silicate powder and $\mathrm{NaOH}$," Cement and Concrete Composites, vol. 34, no. 7, pp. 809-818, 2012.

[25] S. Ahmari, L. Zhang, and J. Zhang, "Effects of activator type/ concentration and curing temperature on alkali-activated binder based on copper mine tailings," Journal of Materials Science, vol. 47, no. 16, pp. 5933-5945, 2012.
[26] N. K. Lee and H. K. Lee, "Reactivity and reaction products of alkali-activated, fly ash/slag paste," Construction and Building Materials, vol. 81, pp. 303-312, 2015.

[27] R. San Nicolas, S. A. Bernal, R. Mejía de Gutiérrez, J. S. J. van Deventer, and J. L. Provis, "Distinctive microstructural features of aged sodium silicate-activated slag concretes," Cement and Concrete Research, vol. 65, pp. 41-51, 2014.

[28] F. Puertas, M. Palacios, H. Manzano, J. S. Dolado, A. Rico, and J. Rodríguez, "A model for the C-A-S-H gel formed in alkaliactivated slag cements," Journal of the European Ceramic Society, vol. 31, no. 12, pp. 2043-2056, 2011.

[29] N. Marjanović, M. Komljenović, Z. Baščarević, V. Nikolić, and R. Petrović, "Physical-mechanical and microstructural properties of alkali-activated fly ash-blast furnace slag blends," Ceramics International, vol. 41, no. 1, pp. 1421-1435, 2015.

[30] B. S. Gebregziabiher, R. Thomas, and S. Peethamparan, "Very early-age reaction kinetics and microstructural development in alkali-activated slag," Cement and Concrete Composites, vol. 55, pp. 91-102, 2015.

[31] M. Chi, "Effects of dosage of alkali-activated solution and curing conditions on the properties and durability of alkaliactivated slag concrete," Construction and Building Materials, vol. 35, pp. 240-245, 2012.

[32] C. Shi, "Strength, pore structure and permeability of alkaliactivated slag mortars," Cement and Concrete Research, vol. 26, no. 12, pp. 1789-1799, 1996.

[33] Y. M. Gu, Y. H. Fang, D. You, Y. F. Gong, and C. H. Zhu, "Properties and microstructure of alkali-activated slag cement cured at below- and about-normal temperature," Construction and Building Materials, vol. 79, pp. 1-8, 2015.

[34] China Standardization Administration, Gb/T 8074-2008, Testing Method for Specific Surface of Cement-Blaine Method, China Standards Press, Beijing, China, 2008.

[35] C. Wang, P. Wen, M. Wang, Q. Fan, and X. Wang, "Preparation and characterization of road alkali-activated blast furnace slag paste," Construction and Building Materials, vol. 181, pp. 175-184, 2018.

[36] W. Shen, Y. Wang, T. Zhang, M. Zhou, J. Li, and X. Cui, "Magnesia modification of alkali-activated slag fly ash cement," Journal of Wuhan University of Technology-Materials Science Edition, vol. 26, no. 1, pp. 121-125, 2011.

[37] M. Hojati and A. Radlińska, "Shrinkage and strength development of alkali-activated fly ash-slag binary cements," Construction and Building Materials, vol. 150, pp. 808-816, 2017.

[38] Standardization Administration of the People's Republic of China, GB/T 1346-2011: Test Methods for Water Requirement of Normal Consistency, Setting Time and Soundness of the Portland Cement, China Standards Press, Beijing, China, 2011.

[39] China Standardization Administration, GB/T 8077-2012, Methods for Testing Uniformity of Concrete Admixture, China Standards Press, Beijing, China, 2012.

[40] National Development and Reform Commission of People's Republic of China, JC/T 603-2004: Standard Test Method for Drying Shrinkage of Mortar, China Building Materials Industry Press, Beijing, China, 2004.

[41] C. K. Yip, G. C. Lukey, and J. S. J. van Deventer, "The coexistence of geopolymeric gel and calcium silicate hydrate at the early stage of alkaline activation," Cement and Concrete Research, vol. 35, no. 9, pp. 1688-1697, 2005.

[42] O. Burciaga-Díaz and J. I. Escalante-García, "Structure, mechanisms of reaction, and strength of an alkali-activated blast-furnace slag," Journal of the American Ceramic Society, vol. 96, no. 12, pp. 3939-3948, 2013. 
[43] A. Fernandez-Jimenez and F. Puertas, "Setting of alkaliactivated slag cement. Influence of activator nature," $A d$ vances in Cement Research, vol. 13, no. 3, pp. 115-121, 2001.

[44] F. Puertas, C. Varga, and M. M. Alonso, "Rheology of alkaliactivated slag pastes. Effect of the nature and concentration of the activating solution," Cement and Concrete Composites, vol. 53 , pp. 279-288, 2014.

[45] K. Komnitsas, D. Zaharaki, and V. Perdikatsis, "Effect of synthesis parameters on the compressive strength of lowcalcium ferronickel slag inorganic polymers," Journal of Hazardous Materials, vol. 161, no. 2-3, pp. 760-768, 2009.

[46] A. Allahverdi, E. N. Kani, and M. Yazdanipour, "Effects of blast-furnace slag on natural pozzolan-based geopolymer cement," Ceram-Sil, vol. 55, no. 1, pp. 68-78, 2011.

[47] F. Puertas and M. Torres-Carrasco, "Use of glass waste as an activator in the preparation of alkali-activated slag. Mechanical strength and paste characterisation," Cement and Concrete Research, vol. 57, pp. 95-104, 2014.

[48] A. A. M. Neto, M. A. Cincotto, and W. Repette, "Drying and autogenous shrinkage of pastes and mortars with activated slag cement," Cement and Concrete Research, vol. 38, no. 4, pp. 565-574, 2008.

[49] N. K. Lee, J. G. Jang, and H. K. Lee, "Shrinkage characteristics of alkali-activated fly ash/slag paste and mortar at early ages," Cement and Concrete Composites, vol. 53, pp. 239-248, 2014.

[50] W. Hansen, "Drying shrinkage mechanisms in Portland cement paste," Journal of the American Ceramic Society, vol. 70, no. 5, pp. 323-328, 1987.

[51] A. R. Brough and A. Atkinson, "Sodium silicate-based, alkaliactivated slag mortars: Part I. Strength, hydration and microstructure," Cement and Concrete Research, vol. 32, no. 6, pp. 865-879, 2002.

[52] A. M. Rashad, S. R. Zeedan, and A. A. Hassan, "Influence of the activator concentration of sodium silicate on the thermal properties of alkali-activated slag pastes," Construction and Building Materials, vol. 102, pp. 811-820, 2016.

[53] A. F. Abdalqader, F. Jin, and A. Al-Tabbaa, "Characterisation of reactive magnesia and sodium carbonate-activated fly ash/ slag paste blends," Construction and Building Materials, vol. 93, pp. 506-513, 2015.

[54] H. El-Didamony, A. A. Amer, and H. Abd Ela-ziz, "Properties and durability of alkali-activated slag pastes immersed in sea water," Ceramics International, vol. 38, no. 5, pp. 3773-3780, 2012.

[55] J. I. Escalante-Garcia, A. F. Fuentes, A. Gorokhovsky, P. E. Fraire-Luna, and G. Mendoza-Suarez, "Hydration products and reactivity of blast-furnace slag activated by various alkalis," Journal of the American Ceramic Society, vol. 86, no. 12, pp. 2148-2153, 2003.

[56] S. A. Bernal, R. M. de Gutierrez, J. L. Provis, and V. Rose, "Effect of silicate modulus and metakaolin incorporation on the carbonation of alkali silicate-activated slags," Cement and Concrete Research, vol. 40, no. 6, pp. 898-907, 2010.

[57] U. Rattanasak, K. Pankhet, and P. Chindaprasirt, "Effect of chemical admixtures on properties of high-calcium fly ash geopolymer," International Journal of Minerals, Metallurgy, and Materials, vol. 18, no. 3, pp. 364-369, 2011.

[58] M. Komljenović, Z. Baščarević, and V. Bradić, "Mechanical and microstructural properties of alkali-activated fly ash geopolymers," Journal of Hazardous Materials, vol. 181, no. 1-3, pp. 35-42, 2010.

[59] Y. Ma, J. Hu, and G. Ye, "The pore structure and permeability of alkali activated fly ash,” Fuel, vol. 104, pp. 771-780, 2013. 


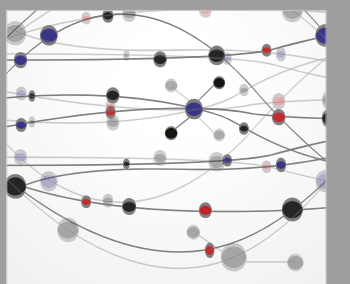

The Scientific World Journal
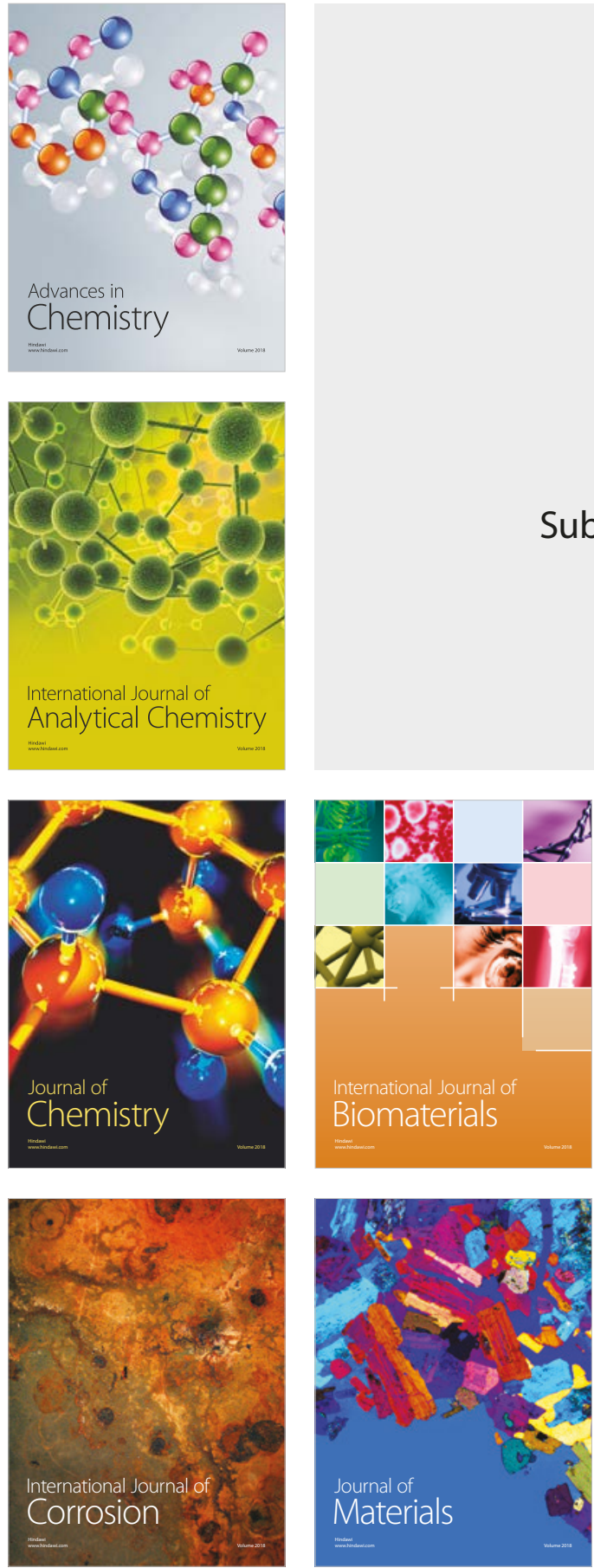

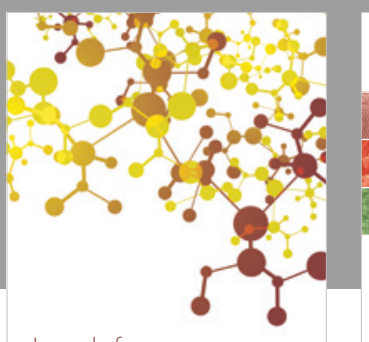

Journal of

Applied Chemistry
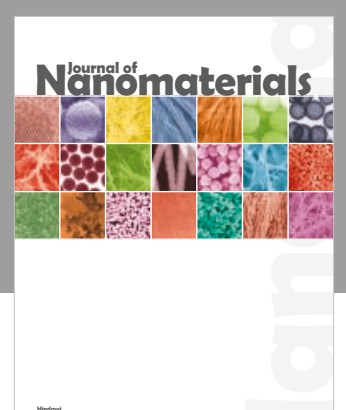

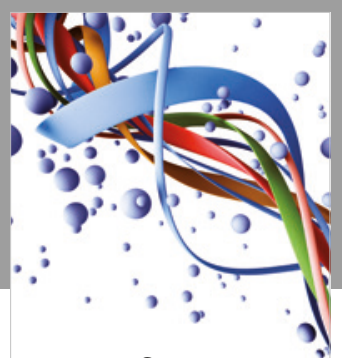

Scientifica

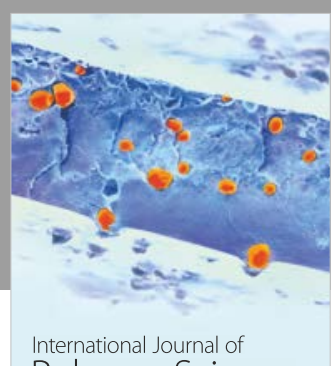

Polymer Science

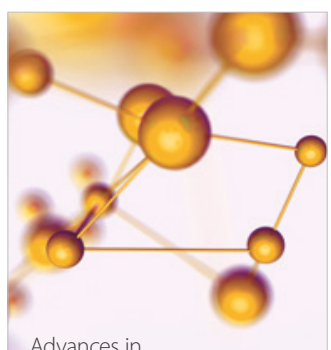

Physical Chemistry
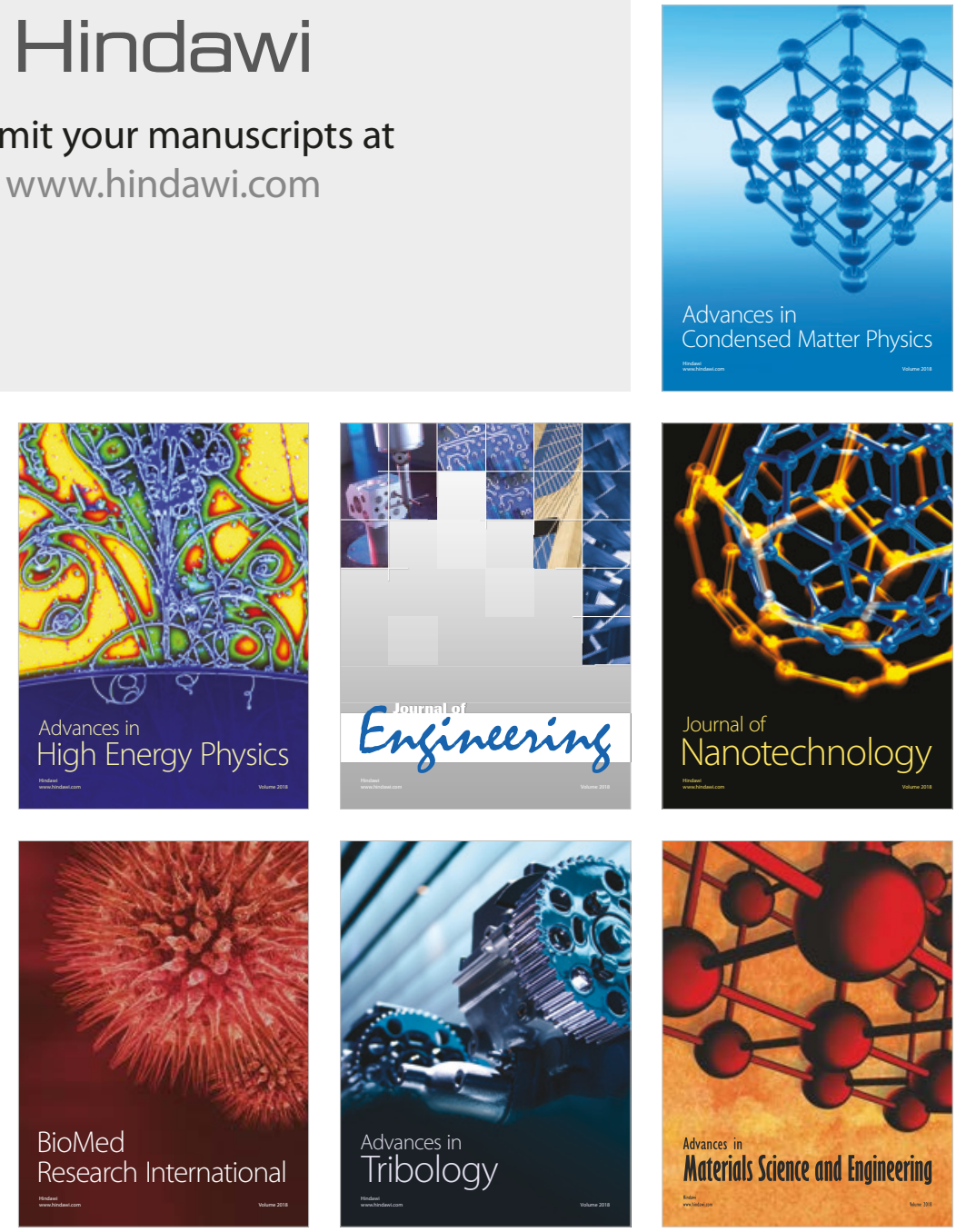